\begin{tabular}{r|l|l|l}
$\begin{array}{c}\text { Case Reports in } \\
\text { Gastroenterology }\end{array}$ & $\begin{array}{l}\text { Case Rep Gastroenterol 2011;5:33-39 } \\
\text { DOl: 10.1159/000323386 }\end{array}$ & $\begin{array}{l}\text { Published online: } \\
\text { January 14, 2011 }\end{array}$ & $\begin{array}{l}\text { O 2011 S. Karger AG, Basel } \\
\text { ISSN 1662-0631 } \\
\text { www.karger.com/crg }\end{array}$ \\
\hline
\end{tabular}

This is an Open Access article licensed under the terms of the Creative Commons AttributionNonCommercial-NoDerivs 3.0 License (www.karger.com/OA-license), applicable to the online version of the article only. Distribution for non-commercial purposes only.

\title{
A Large Portal Vein: A Rare Finding of Recent Portal Vein Thrombosis
}

\author{
Xingshun Qi $^{\mathrm{a}} \quad$ Guohong Han ${ }^{\mathrm{a}}$ Zhanxin Yin ${ }^{\mathrm{a}}$

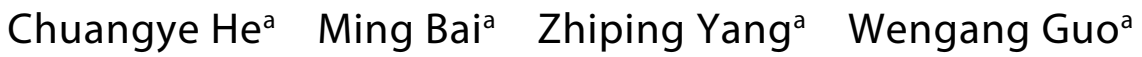 \\ Jing Niu ${ }^{a}$ Kaichun $\mathrm{Wu}^{\mathrm{a}, \mathrm{b}}$ Daiming Fan ${ }^{\mathrm{a}, \mathrm{b}}$ \\ aDepartment of Digestive Interventional Radiology, and 'bState Key Laboratory of \\ Cancer Biology, Xijing Hospital of Digestive Diseases, Fourth Military Medical \\ University, Xi'an, China
}

\section{Key Words}

Portal vein thrombosis - Computed tomography · Anticoagulation - Thrombolysis

\begin{abstract}
Acute portal vein thrombosis (PVT) is rarely encountered by clinicians. The most common manifestation of acute PVT is sudden onset of abdominal pain. A computed tomography scan without contrast often shows a high-density material in the portal vein. After injection of contrast agents, absence of luminal enhancement and enlargement of the obstructed portal vein are shown. In this case report, we demonstrated a rare computed tomography finding in which the diameter of the main portal vein was enormously distended to 3-fold that of the aorta in a patient with recent PVT. Despite thrombolysis and anticoagulation were immediately given, portal venous recanalization was not achieved in the patient. After 5 years, variceal bleeding and ascites occurred and liver function had persistently deteriorated. Finally, he died of progressive liver failure. Considering this case, we suggest that an early decision for invasive interventional treatment might be necessary to both increase the rate of portal venous recanalization and improve prognosis, as anticoagulation and thrombolysis therapy failed to recanalize recent PVT.
\end{abstract}

\section{Case Report}

In August 2004, a previously healthy 31-year-old male was referred to the emergency department due to a 5-day history of progressing abdominal pain. Physical examination revealed diffuse tenderness of the abdomen, without significant rebound or guarding. An emergency non-enhanced computed tomography (CT) of the liver (fig. 1a, c, e) showed a high luminal density within the main portal vein and splenic vein, which was suggestive of the formation of fresh thrombus; a contrast-enhanced CT scan at the portal phase (fig. $1 \mathrm{~b}, \mathrm{~d}, \mathrm{f}$ ) demonstrated that the diameter of the main portal vein was distended to 


\begin{tabular}{r|l|l|l} 
Case Reports in & $\begin{array}{l}\text { Case Rep Gastroenterol 2011;5:33-39 } \\
\text { DOl: } 10.1159 / 000323386\end{array}$ & $\begin{array}{l}\text { Published online: } \\
\text { January 14, 2011 }\end{array}$ & $\begin{array}{l}\odot \text { ISSN 1662-0631 } \\
\text { www.karger.com/crg }\end{array}$ \\
\hline
\end{tabular}

nearly 3 -fold that of the aorta, and a few fine collateral vessels developed around the thrombosed portal trunk in the liver hilum. To recanalize the thrombosed portal vein and prevent thrombus extension, a 48-h continuous infusion of urokinase into the superior mesenteric artery was initially employed. Subsequently, heparin was administered intravenously at a starting dose of $1,000 \mathrm{U} / \mathrm{h}$ for 5 days. The abdominal pain resolved after the thrombolytic and anticoagulant therapy. The patient's thrombophilia screen results were normal, including antithrombin III deficiency, protein $\mathrm{C}$ and protein $\mathrm{S}$ deficiency, factor V Leiden and antiphospholipid antibody. Oral warfarin was prescribed for 6 months. During follow-up, a color Doppler ultrasound examination showed that the main portal vein was replaced by numerous collateral veins in the liver hilum.

In November 2009, the patient presented with repeated abdominal distension and a recent episode of variceal hemorrhage that was controlled by medical therapy. At admission, physical examination revealed splenomegaly and abdominal bloating. He had an impaired liver function with a Child-Pugh class $C$ and a MELD score of 16.8 points. A low platelet count of $69,000 \mathrm{~mm}^{3}$ and a low hemoglobin concentration of $108 \mathrm{~g} / \mathrm{l}$ were also observed. JAK2 V617F gene mutation was negative. The CD55- and CD59-deficient clones were not found. Ascites and splenomegaly were shown on a contrast-enhanced CT scan (fig. 2). Indirect portography via superior mesenteric artery revealed numerous hepatopetal collateral vessels in the liver hilum (fig. 3a). These findings suggested the formation of extrahepatic portal hypertension. Subsequently, a transjugular intrahepatic portosystemic shunt insertion via a trans-splenic approach was attempted to treat complications of portal hypertension, as previously described [1]. However, the operation failed, because a guidewire and catheter could not access the portal vein (fig. 3b). Thereafter, symptomatic treatment was given. Finally, he died of progressive liver failure in June 2010.

\section{Discussion}

Non-malignant and non-cirrhotic PVT is a rare clinical entity [2]. If acute thrombus extends into mesenteric venous arches, severe complications occur, such as intestinal infarction and even peritonitis. If the portal vein obstruction is not timely recanalized, cavernous transformation of the portal vein develops and pre-hepatic portal hypertension might cause complications, such as variceal bleeding and ascites. Accordingly, both early differential diagnosis and intervention are very critical in the emergency situation.

CT has been considered a mainstay diagnostic modality of PVT by visualization of its associated abnormalities. The CT imaging features that are specific to recent PVT include a high-density material in the portal vein on non-enhanced CT scans and enlargement of the obstructed portal vein on contrast-enhanced CT scans [3]. On non-enhanced CT scans, a fresh thrombus usually appears as a hyperattenuating material in the portal vein, because the protein fraction of hemoglobin in the clot results in the elevated CT attenuation value [4]. Dilation of the portal vein is also regarded as a CT feature at the early stage of PVT [5]. However, to our knowledge, such a great dilation of the main portal vein as in our patient has rarely been reported. Additionally, it should be noted that this rare CT feature might lead to an erroneous diagnosis of the pancreatic mass (fig. 1d, f), because the enlarged portal vein was anatomically adjacent to the pancreatic head.

In the current practice guidelines, anticoagulation was considered as the first-line therapy for acute PVT in non-malignant and non-cirrhotic patients [6, 7]. However, a recent prospective cohort study demonstrated that approximately $70 \%$ of patients would not achieve portal vein recanalization, despite anticoagulation therapy was immediately given [8]. If so, prehepatic portal hypertension would occur in a high proportion of patients with PVT. Thus, one important issue is questioned: 'how should we treat these patients?' Experts advocated that 'patients with extrahepatic PVT who have 


\begin{tabular}{r|l|l|l}
$\begin{array}{r}\text { Case Reports in } \\
\text { Gastruanterology }\end{array}$ & $\begin{array}{l}\text { Case Rep Gastroenterol 2011;5:33-39 } \\
\text { DOI: 10.1159/000323386 }\end{array}$ & $\begin{array}{l}\text { Published online: } \\
\text { January 14, 2011 }\end{array}$ & $\begin{array}{l}\text { O 2011 S. Karger AG, Basel } \\
\text { ISSN 1662-0631 } \\
\text { www.karger.com/crg }\end{array}$ \\
\hline
\end{tabular}

portal hypertension but do not bleed from the varices should be observed, because bleeding may not occur for many years' $[9,10]$. However, considering our case, the 'wait and see' attitude appears to be not completely appropriate. This consideration mainly originates from the fact that the long-term outcome was poor in our case, as portal venous recanalization was not achieved by thrombolysis and anticoagulation. We hypothesized that if an early aggressive interventional treatment was carried out in the patient, portal venous recanalization rate would be elevated and portal hypertension might be avoided, thereby improving the long-term survival.

\section{Disclosure Statement}

There are no conflicts of interest. 


\begin{tabular}{l|l|l|l}
$\begin{array}{r}\text { Case Reports in } \\
\text { Gastruenterology }\end{array}$ & $\begin{array}{l}\text { Case Rep Gastroenterol 2011;5:33-39 } \\
\text { DOI: 10.1159/000323386 }\end{array}$ & $\begin{array}{l}\text { Published online: } \\
\text { January 14, 2011 }\end{array}$ & $\begin{array}{l}\text { O 2011 S. Karger AG, Basel } \\
\text { ISSN 1662-0631 } \\
\text { www.karger.com/crg }\end{array}$ \\
\hline
\end{tabular}
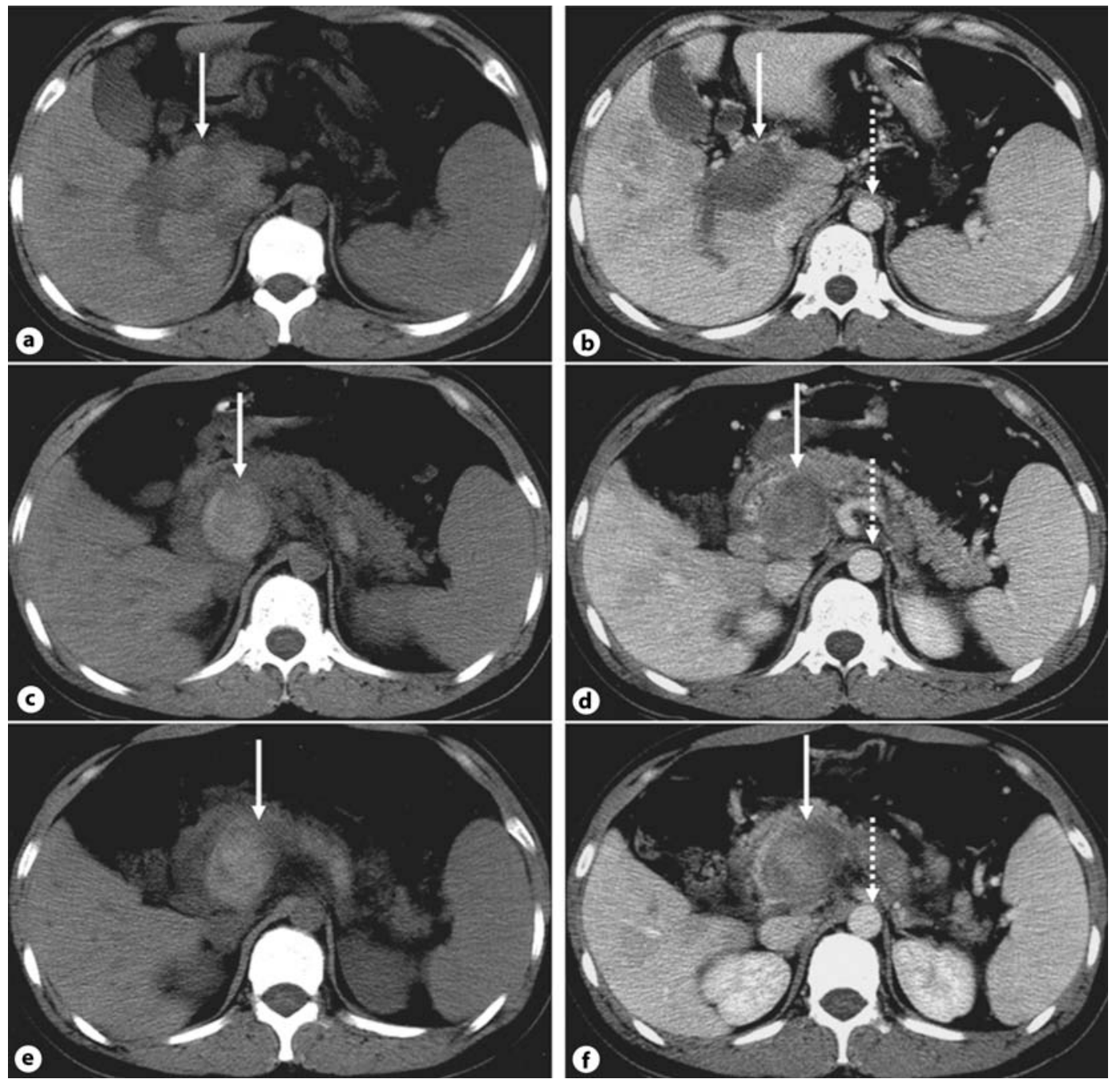

Fig. 1. Axial computed tomography of the liver at the phase of recent portal vein thrombosis. Solid and dashed arrows indicate the enlarged portal vein and the aorta, respectively. 


\begin{tabular}{r|l|l|l}
$\begin{array}{r}\text { Case Reports in } \\
\text { Gastruanteriology }\end{array}$ & $\begin{array}{l}\text { Case Rep Gastroenterol 2011;5:33-39 } \\
\text { DOI: 10.1159/000323386 }\end{array}$ & $\begin{array}{l}\text { Published online: } \\
\text { January 14, 2011 }\end{array}$ & $\begin{array}{l}\text { O 2011 S. Karger AG, Basel } \\
\text { ISSN 1662-0631 } \\
\text { www.karger.com/crg }\end{array}$ \\
\hline
\end{tabular}
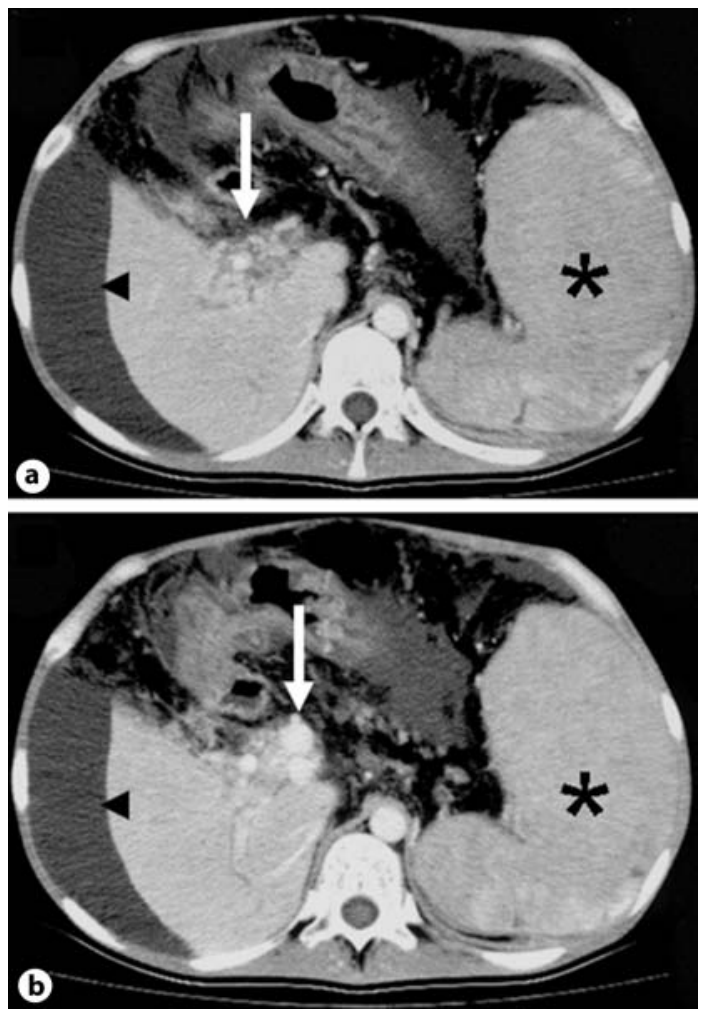

Fig. 2. Axial computed tomography of the liver at the phase of portal cavernoma. Arrows indicate the hilum in which the main portal vein was replaced by collateral vessels. Arrowheads and asterisks indicate the ascites and splenomegaly, respectively. 


\begin{tabular}{r|l|l|l}
$\begin{array}{r}\text { Case Reports in } \\
\text { Gastruanteriology }\end{array}$ & $\begin{array}{l}\text { Case Rep Gastroenterol 2011;5:33-39 } \\
\text { DOI: 10.1159/000323386 }\end{array}$ & $\begin{array}{l}\text { Published online: } \\
\text { January 14, 2011 }\end{array}$ & $\begin{array}{l}\text { O 2011 S. Karger AG, Basel } \\
\text { ISSN 1662-0631 } \\
\text { www.karger.com/crg }\end{array}$ \\
\hline
\end{tabular}
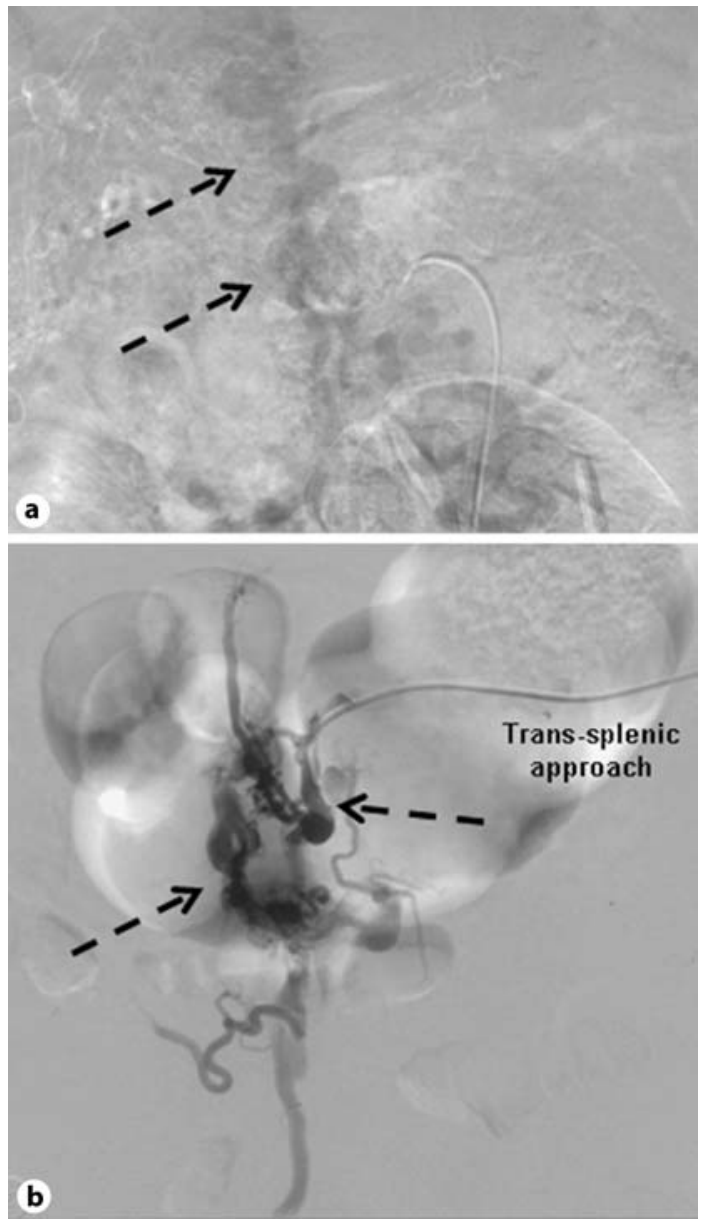

Fig. 3. Indirect portography via superior mesenteric artery (a) and splenoportography (b). Dashed arrows indicate the collateral veins. 


\section{References}

1 Han G, Qi X, He C, et al: Transjugular intrahepatic portosystemic shunt for portal vein thrombosis with symptomatic portal hypertension in liver cirrhosis. J Hepatol 2010;54:78-88.

-2 Valla DC, Condat B: Portal vein thrombosis in adults: pathophysiology, pathogenesis and management. J Hepatol 2000;32:865-871.

3 Mathieu D, Vasile N, Grenier P: Portal thrombosis: dynamic CT features and course. Radiology 1985;154: 737-741.

4 Mori H, Hayashi K, Uetani M, et al: High-attenuation recent thrombus of the portal vein: CT demonstration and clinical significance. Radiology 1987;163:353-356.

5 Miller VE, Berland LL: Pulsed Doppler Duplex sonography and CT of portal vein thrombosis. AJR Am J Roentgenol 1985;145:73-76.

6 DeLeve LD, Valla DC, Garcia-Tsao G: Vascular disorders of the liver. Hepatology 2009;49:1729-1764.

7 de Franchis R: Revising consensus in portal hypertension: Report of the Baveno V consensus workshop on methodology of diagnosis and therapy in portal hypertension. J Hepatol 2010;53:762-768.

$\checkmark 8$ Plessier A, Darwish-Murad S, Hernandez-Guerra M, et al: Acute portal vein thrombosis unrelated to cirrhosis: A prospective multicenter follow-up study. Hepatology 2010;51:210-218.

-9 Triger DR: Extra hepatic portal venous obstruction. Gut 1987;28:1193-1197.

10 Sarin SK, Kumar A: Noncirrhotic Portal Hypertension. Clin Liver Dis 2006;10:627-671. 